\title{
Working Environment of Academic Staff in Federal State and Private Universities in Delta State
}

\author{
Dr. Joseph Efe Anho Ph.D. \\ Department of Educational Management and Foundations \\ Delta State University \\ Abraka
}

University as a tertiary education is regarded as an instrument of social change and economic development. According to the Federal Republic of Nigeria in its National Policy on Education Section 8 (59) tertiary education which include universities is expected to: contribute to national development through high level, relevant manpower training, develop and inculcate proper values for the survival of the individual and society, develop the intellectual capability of individuals to understand and appreciate their local and external environments, acquire both physical and intellectual skills which will enable individuals to be self-reliant and useful members of the society, promote and encourage scholarship and community service, forge and cement national unity and promote national and international understanding and interaction.

Despite the immense benefits of university education to nation building, the potentials of higher education and indeed the university system in developing countries to fulfill its responsibility is frequently thwarted by longstanding problems bedeviling the system. Ajayi and Ayodele (2002), opined that higher education in Nigeria is in travail, the system is riddled with crises of various dimensions and magnitude. A number of multi-faceted problems have inhibited goal attainment and are raising questions, doubts and fears, all of which combine to suggest that the system is at a crossroad. The university is globally known to be a centre for teaching, learning, researching a and citadel of academic excellence. The ability of any university to take off and achieve its goals is a function of its ability to attract, retain and maintain competent and satisfied staff into its employment. The university is an institution of higher learning that provides manpower needs to advance national development in both the public and private sector.

University staff are still at the forefront of agitation for better working condition however this development has serious implication on the motivational and commitment level of the academic staff, an attractive salary and other working conditions serve as a major motivational tool which spurs teachers to put in their best, and as well compensate for individual investment in preparation for their acquired skilled (www.nuc.com). Okeke (2004) asserted that no teacher can produce his best or put in more enthusiastic effort if he believes he is under-paid. Similarly to the salary issue, is the case of delays in promotions; it is usually accompanied by salary review. This development leaves academic staff stagnated at a certain career grade level, thereby denying such personnel the financial and non-financial benefits accruable from such upward career movement. Aside issues of salaries and promotions, the academic staff in universities are bedeviled with a lot of inadequacies and shortage in working materials. According to Anho (2017) this regrettable situation has seriously handicapped the average staff, lowered his morale, and eroded his enthusiasm and belief in the teaching profession, thereby lowering his level of effectiveness in the school. It is commonplace to find in our universities, libraries and laboratories existing only in nomenclature rather than functionality. In other instances academic staff has to buy with their own salaries stationeries and recommended texts to aid their teaching work. The success of any educational system (university) and productivity of all academic staff depend highly on their working environment. The basic concept applicable to the study is that the maximum impact of working environment would only be realized when there is condusive working environment for the academic study. This is so as the school environment is an important instrument in bringing about effectiveness of academic staff in performing their duties in the teaching learning and research process. The Federal Republic of Nigeria (2014) in the National Policy on education emphasized among other things the acquisition of knowledge, skills and competence for self-actualization, selfreliance, socio-economic and technological growth and development.

Studies have shown that working environment is a contributing factor to the productivity of academic staff. Their work environment may make them irritable and less enthusiastic about their job. The absence of a desirable pay package, irregular promotions, inadequate essential staff support services, and depressing social environment, presence of decrepit school facilities, all contribute to increase the anger, stress, dissatisfaction and frustration of academic staff. Although, the government generally welcomes the participation of private individuals in providing education for its learning population, while some of the states and private universities are doing well, others seem to have nothing to offer to the society as they lack lots of infrastructure and manpower which are the basic requirements of the provision. 
As a result of this, questions have been asked whether the proprietor of state and private universities comply with the rules and regulation set down by the National Universities Commission (NUC) for the operation of universities A proper environment where teaching, learning and research takes place within the content of the policy must be functional, to enable academic staff and learners attain the goals of education. However, observation has also shown that the working environment of academic staff influences their duties in achievement of education goals, yet it is one of the most ill-managed and haphazardly handled areas in education. One therefore wonders if the National Universities Commission whose duty is to set, maintain, monitor, implement and improve standards in all university is really performing its responsibilities. Circumstance of funding, autonomy, promotion, working conditions, lack of offices, lack of staff facilities, electricity, water, no internet facilities for research work amongst others, are really disheartening in federal, state and private universities. Thus, academic staffs find themselves in a physical environment that adversely affect their morals and in some cases their health. Most academic staff in schools especially those in federal and state universities have complained that their performances suffer as a result of the unconducive nature of their environment in the universities.

The pertinent questions that arise therefore is; what are the types of working environment found in federal, state and private universities in Delta State? How does the environment influence the duties of academic staff in federal, state and private universities in Delta State? What are the management strategies employed by academic staff in order to improve the working environment in federal, state and private universities? To what extent does academic staff in federal, state and private universities comply to the set rules and regulations of the institutions relating to their working environment? It is against this backdrop that the researcher is interested in comparing the working environment of academic staff in federal, state and private universities in Delta State. This study will be restricted to only academic staff from the rank of assistant lecturer to senior lecturer because of their number and accessibility.

\section{Theoretical Framework}

The theoretical framework used for this research is the Resource Dependency Theory by Duncan (1972) who emphasized the importance of resources to organizations continual operation and survival. The resource dependency theory views the working environment in terms of relative scarcity of resources and emphasized that the university system cannot survive without resources drawing from the theory, the challenges for academic staffs is to determine the extent to which they can and must respond to various depends of school programmes in respect to the working environment without potentially affecting the entire operation adversely such as riot or not complete the course on schedule or total disruption of academic calendar. From the work of Duncan, the effective utilization of working environment for teaching and learning is based on sound perception of the task to be done which is reflected in the exhibition of patterns by stakeholder that stimulate academic staffs and learners to attain desire goals. If this is not done, both academic staffs and learners face role strain that can lead to poor performance in the school system. In consideration of Duncan theory, the researcher believes that if all academic staff, management, parents and stakeholders in the university system can see the working environment as assets that are valuable to the achievement of the educational goals of the society, the administration, utilization, management and maintenance of the working environment will be a priority for all, thus, this will go a long way to make the working environment beautiful, developmental, sustainable, productive and a pride to the society and ensure the comfort ability of the working environment to both academic staffs and learners.

In this Duncan study, the provision, utilization, management, maintenance procedure are expected to be based on some strategies while the availability and adequacy of working environment are expected to satisfy the number of academic staff to be served and the desired objectives to be achieved by the institution. Therefore, the Duncan Resource Dependency theory concentrates on the importance of the quantity and quality of resources as the major determinant of the proceeds of the working environment. Consequently, effective management and maintenance strategies, the level of resources available to the educational system and the way they are put to use determines and to a great extent affect the performance of academic staff of that education system. With this theory serving as the background, the study seek to investigate the impact of working environment on academic staff in federal, state and private universities in Delta State.

\section{Types of Working Environment}

This represents all the elements existing in the school system that interfaces with the academic staffs and which influences his level of productivity. Such factors offer the teacher intrinsic and extrinsic utility. They comprise of condition of service such as salaries, promotions, incentives and allowances, pension matters, conducive school environment, availability of teaching materials/facilities, administrative tone of the school, workload, lack of autonomy and recognition. 
a. Salary: This is most worker's desired job reward. It is their reason of engaging in work, it is their sole agent of social and economic mobility. In separate studies by Adelabu (2005), Afe (2006) and Gana (2011), they reveal that salaries influence worker's morale, work attitude and effectiveness greatly and that no satisfaction can surpass that derived from an adequate regular salary. Its potency in determining level of productivity in the organizations is unequalled by other working conditions little wonder according to Eze, (2006) it accounts for 60\% of industrial disputes between employers and employees.

b. Promotion: Promotion in the perspective of workers is the endorsement and evidential certification of their years of committed service. It is the loyalty reward a worker receives for staying on the job and it is the premise upon which a worker assumes new official and economic status, as well as new responsibilities. Workers generally hold it dearly and therefore irregularity in its implementation, poses grave consequences on teachers' job morale (Adelabu, 2005).

c. Fringe Benefits: Some employees are usually paid extra compensation by their employers aside their regular salary by virtue of their organizational membership (Okeke, 2004). Benefits have its main aim, to secure employee's commitment and also to retain the services of some exceptional personnel.

d. Pension and Gratuity: This is a fixed amount of money paid to a retired worker on a regular basis usually monthly. Okeke (2004) asserts that teacher's morale and effectiveness can be impaired from continuous worry about the uncertainty of post service life. Such worries Okeke noted, distracts the teacher from performing very well on his job.

2. Funding: Ibukun (1997) lamented that there is growing shortage of funds and learning resources in the education system. Ajayi and Ayodele (2002) argued that there was an increase in the proportion of total expenditure devoted to education, but this has been considered to be rather grossly inadequate considering the phenomenon increase in student enrolment and increasing cost, which has been aggravated by inflation and job frustrating conditions. Besides, Ajayi and Ekundayo (2006) remarked that the Nigerian government over the years has not been meeting the United Nations Educational Scientific and Cultural Organization (UNESCO) recommendation of 26\% of the total budget allocation to education sector. Oshuntokun (2006) noted that under funding remain the major hindrance to the development of the nation in particular and the education sector and by extension to national development, according to Oshuntokun (2006), there is correlation between under funding of universities and national development. According to Oyeneye (2006) and Adegbite (2007), the major challenge facing the education system in Nigeria is inadequate funding, meanwhile without funding research work can't be done thus affecting the working environment of academic staff. These revelations expose the extent to which the government itself is a contributing factor to the financial imbroglio of the university system. The apparent shortage of fund available to the university system has been responsible for declining, infrastructure, library, social and laboratory and research facilities in Nigerian universities in recent years.

3. Physical Working Condition: It is worrisome to note that education system in Nigerian are fast decaying. All the resources required for education production process are in short supply, halls, laboratories, students' hostels, library space, books and journals and office spaces are all seriously inadequate. According to World Bank (1994), the equipment for teaching, research and learning are either lacking or very inadequate and in a bad shape to permit the universities the freedom to carry out the basic function of academics. Meanwhile, this condition of resource inadequacy is what Ajayi and Ayodele (2002) described as an offshoot of the endemic financial crisis in the sector. Anho (2017) in his research discovered that there is a correlation between physical and fiscort resources.

\section{The Concept of Educational facilities}

Educational facilities refer to the physical resources of a school. It involves the entire maximum productivity and effectiveness at minimum cost. These facilities include school site, land and building of lecture hail, staff offices, laboratories, the! space for housing the equipment and the environment. School plants are the site, building and equipment. It embraces both permanent and semi-permanent structure as well as items like machinery, laboratories equipment, chalkboard and even cleaner tools. The site is the specific geographical location that contains thy building where the school equipment is kept for educational use. The term educational facilities have been defined in various ways by different authorities. It is most often referred to as school plant, physical facilities or infrastructural facilities. Castaldi (1997) sees educational facilities as those things relating to education which enable a skillful; teacher to achieve a level of instructional effectiveness that supersedes what is possible when they are not there. These educational facilities are enormous and they include whatever materials and services that help to facilitates the teaching and learning process. Educational facilities can be called school plant. He further defines it as the space and physical resources that a school administrator and his staff harness, distribute, utilize and maintains for effective school administrators, teaching and learning. Moreover, educational facility has something much more than just the school building, recognizing the school building as the central element. To him, it include; classrooms, corridors, lightings, sanitary facilities, recreational facilities, furniture, 
Equipment as well as other consumable and non-consumable supplies required for the achievement of instructional and educational objectives. In fact, the term educational facilities can be deduced from a consensus definition which says it include all physical objects within the school which help to improve teaching and learning activities. Therefore, these facilities are very important and directly related to school curriculum in the attainment of educational objectives as they help create a congenial environment where leaning can be made easy and useful. As inefficiently used building, unpleasant and colorless rooms or poorly maintained site inhibit the development of a good educational program and reduce staff and students' morale.

\section{Adequacies of Infrastructural Facilities}

In the school system, like any other organization people tend to perform better in the surrounding and facilities that are appropriate for the work. Therefore, the provision and maintenance of the physical well-being of both the student, staff, educational facilities and equipment, the provision of space for offices, staff offices, laboratories, lecture halls, libraries, guidance and counseling rooms, toilet for both staff and students are paramount to school administrator's task. Consequently, Educational facilities can be seen as the physical resources which school administrators, teachers and students harness, allocate, and utilize for the purpose of effective school administration, and the teaching/learning process. Particularly, educational facilities can be described to entail the building, sport facilities, study facilities and teaching aids. This invariably means funding is vital and related to the provision of facilities. In addition, the upper limit of educational facilities is reached when facilities for the effective teaching and learning can no longer be tendered to more students without incurring declining returns. This is seen in the over stretched educational facilities and poor quality of academic staff in most universities which is giving rise to alleged declined in educational standard.

Conducive offices: For effective teaching and learning, the academic staffs are as imperative as appropriate instructional materials. This human resource component is indispensable in the teaching and learning process. Their comfort should therefore be sought and should be adequately provided. The staffroom and administrative offices should be available and conducive for academic staff in the system. The performance of an academic staff to school goal attainment requires the supply of conducive staffrooms/offices o work in. Such accommodation should be one that possesses every element of safety, comfort and aesthetics. A conducive office should have the following; Suitable and dignified functional furniture, functional windows and doors, adequate ventilation system, effective lighting system and neatness. (Afe 2006)

\section{Functional Libraries and Laboratories}

The library is a place or building where books and other audio-visual materials are organized and stored for use (Aliu and Ogborno, 2007). It is a repository of knowledge upon which the foundation of the school is laid. According to De Chiara and Crosbie (2001) educational needs have changed and the amount of information essential for nurturing the maturing of people has virtually exploded, the character of the school library has also changed. It has become larger and functional; academic staff put into a more intimate relationship with textbooks, journal, articles, pamphlet and other media used in transmitting ideas and information. They further stated that a functional library operating as an instructional material centre should include room, shelves, magazines, pamphlets, study conference and viewing audiovisual equipment, librarian office, library workroom and so on. Also, texts of all subjects offered in the school should be stocked in the school library for easy access to both teachers and students. The use of material resources in teaching involves facilitation of learning through the manipulation of devices, appliance that stimulates, sustain and invigorate learning, without the provision of adequate laboratory and laboratory equipment, student cannot have the perception of facts which are needed for proper judgement. Ukachukwu (2008) noted that science subjects are better taught through practical demonstrations. This method leaves a lasting retention of ideas in the mind because it recruits almost all the human senses which were by far a more effective teaching-learning strategy (Dike, 2002). Frustration of science academic staff arises when he/she realizes that he cannot lecture effectively a topic that requires a practical session, simply because laboratory resources are absent. Work group Esprit de corp is quite a relative new variable linked to job satisfaction or job dissatisfaction. Work espir it de corps refers specially to the extent to which member takes pride in their work group (Jones and James, 1979). It has been used as a vital component of an organization's psychological climate, which in turn is thought to influence job satisfaction or dissatisfaction. In addition, the notion that interpersonal relation among workers may lead to certain group dynamics, which in turn affect organizational productivity can be traced to the human relations approach and its focus on the human factor in the work place.

Organizational Climate: Researchers in organizational behavior have long been interested in understanding employees' perceptions of the work environment and how these perceptions influence individuals' work- related attitudes and behavior. Early researchers suggested that the social climate or atmosphere created in a workplace had significant consequences employees' perceptions of the work context purportedly influenced the extent to which. 
People were satisfied and perform to their potential, which in turn, was predicted to influence organizational productivity (Katz\& Kahn, 2004 \& McGregor, 2000). The construct of climate has been studied extensively and has proven useful in capturing perceptions of the work context (Denisson, 2006; Kinicki \& Tamkins, 2007).

\section{Methodology}

This chapter describes in details the research methods and procedures used. The research design is the Expost-Facto design of the descriptive survey method to determine the current situation of working environment of academic staff in federal, state and private universities in Delta State. The target population of the study comprised all the academic staff of the Federal, State and private universities in Delta State. The total number of academic staff in Federal University (Federal University of Petroleum Resources Ogbromo Effurun) was 190, State University (Delta State University) was 722 and that of private universities Western Delta University was 84,(Novena University, Ogume was 169 bringing the total number to 1106 academic staff in 2014/2015 session.

\section{Source: National Universities Commission}

The stratified random and purposive sampling technique was used. To sample one federal university, one state university and one private university each from the three senatorial districts in Delta State each. Thus, the Federal University of Petroleum Recourses Ogbromo-Effurun was sampled, representing Delta South. The Delta State University, Abraka was selected from Delta Central and the researcher purposively sampled the Novena University, Ogume as the private university, because it is located in Delta North. Thus, 413 i.e. $40 \%$ of the academic staff was selected randomly from across the various faculties to make up the sampled population. The research instrument used for the study was thirty item (30) questionnaire titled "Working Environment among Academic Staff in Federal, State and Private Universities in Delta State" (WEAASFSPUDESQ). This instrument was designed by the researchers to get the respondent's view. The questionnaire was categorized into two sections; A and B. Section A sought demographic data of respondents while, Section B sought information on the variables of study. All variables were measured using adapted four point likerts scale of Strongly Agree (SA) - 4 point, Agree (A) - 3 point, Strongly Disagree (SD) - 2 point, and Disagree (D) -1 point.

The researcher ensured the validity of the instruments by subjecting the items to experts judgement for validation in the Department of Educational Management and Foundations and Counselling Psychology who are specialist in measurement and evaluation. Their suggestions, comments, criticism and remarks were used to validate and improve the face and content of the instrument. The reliability of the instrument was established using the Split half technique, and was administered to a sample of thirty (30) academic staff; (ten each) from federal (University of Benin, Benin City) Ambroze Ali University Ekpoma (state) western Delta University, Oghara (Private) who were not part of the sample for the study. Their responses were collated and analyzed on the basis of even and odd number items. The Pearson (r) product moment correlation coefficient was used to analyze the two separate responses. The reliability coefficient of the instrument was computed as 0.81 which was considered high enough for the study. The instrument was administered to four hundred and thirteen academic staff (413) of the Federal, State and Private Universities of study in Delta State. This was done with the help of two trained research assistants. At the end of the administration, a total of 406 questionnaires were returned and used representing $98.3 \%$ returned rate. The responses were worked out employing the descriptive statistics and measures of central tendencies. Based on this, the mean and standard deviation analysis of each of the items were raised before determining the cumulative mean analysis of the section with acceptance bench mark of 2.50 and above. The data collected was summarized in tables and hypothesis tested with the analysis of variance (ANOVA) using the statistical package of the social sciences version 17 (SPSS 17). The choice of the ANOVA analysis was made because the analysis of variance establishes differences in mean of multiple groups. The Scheffe test was used to determine area of significance between the variables.

\section{Purpose of the Study}

Generally the purpose of this research is to compare the working environment of federal, state or private universities in Delta State and specifically;

1. Identify the types of working environment among academic staff in federal, state and private universities in Delta State

2. Examine the influence of the working environment on the duties of academic staff in federal, state and private universities in Delta State

3. Find out the management strategies employed to make the working environment more conducise for academic staff in federal, state and private universities. 


\section{Research Question}

The following research questions were raised to guide the research:

1. What are the types of working environment in federal, state and private universities in Delta State?

2. How does the working environment influence the duties of academic staff in federal, state and private universities in Delta State?

3. What management strategies are employed to make the working environment more conducive for academic staff in federal, state and private universities in Delta State?

\section{Hypotheses}

The following null hypotheses were formulated be tested:

$\mathbf{H o}_{1}$ There is no significant difference in the types of working environment among academic staff in federal, state and private universities in Delta State

$\mathbf{H o}_{2}$ There is no significant difference in the influence of working environment on the duties of academic staff in federal, state and private universities in Delta State.

$\mathrm{Ho}_{3}$ There is no significant difference in the management strategies employed to make the working environment more conducive for academic staff in federal, state and private universities in Delta State

Presentation and Analysis of Results

\section{Research Question 1}

What are the types of working environment among academic staff in Federal, State and Private Universities in Delta State?

Table 1: Analysis of mean and standard deviation of the types of working environment among academic staff in federal, state and private universities in Delta State

\begin{tabular}{|c|c|c|c|c|c|c|c|c|c|}
\hline \multirow[t]{3}{*}{$\mathrm{S} / \mathrm{N}$} & \multirow[t]{3}{*}{ Items/Statements } & \multicolumn{4}{|c|}{ Responses } & & & & \multirow[t]{3}{*}{ Decision } \\
\hline & & \multicolumn{2}{|c|}{ Federal } & \multicolumn{2}{|l|}{ State } & \multicolumn{2}{|c|}{ Private } & \multirow[b]{2}{*}{ Average } & \\
\hline & & Mean & SD & Mean & SD & Mean & SD & & \\
\hline 1. & Irregular Promotion & 3.40 & 0.49 & 2.86 & 0.98 & 3.13 & 0.78 & 3.13 & Accepted \\
\hline 2. & Lack of funds for research & 3.13 & 0.66 & 2.55 & 1.03 & 2.76 & 0.74 & 2.81 & Accepted \\
\hline \multirow[t]{2}{*}{3.} & Lack of modern teaching & & & & & & & & \\
\hline & Facilities and equipment & 3.62 & 0.48 & 2.76 & 0.83 & 3.63 & 0.71 & 3.30 & Accepted \\
\hline 4. & Lack of office spaces & 3.28 & 0.72 & 2.76 & 1.03 & 3.43 & 0.50 & 3.15 & Accepted \\
\hline 5. & Lack of regular pay & 3.50 & 0.75 & 2.62 & 1.02 & 3.83 & 0.44 & 3.31 & Accepted \\
\hline 6. & Poor condition of services & 2.84 & 0.65 & 2.95 & 0.96 & 3.04 & 0.63 & 2.94 & Accepted \\
\hline 7. & University autonomy & & & & & & & & \\
\hline \multirow{3}{*}{8.} & Violation & 3.07 & 0.45 & 2.98 & 0.96 & 3.07 & 0.57 & 3.04 & Accepted \\
\hline & Poor spirit de-corps & & & & & & & & \\
\hline & among Academic staff & 2.84 & 0.65 & 2.52 & 1.12 & 3.20 & 0.40 & 2.70 & Accepted \\
\hline \multirow[t]{3}{*}{9.} & Inadequate staff training & & & & & & & & \\
\hline & and development & & & & & & & & \\
\hline & programmes & 3.40 & 0.59 & 2.51 & 1.35 & 3.22 & 0.59 & 3.04 & Accepted \\
\hline
\end{tabular}

Table 1 indicated that all the Nine (9) items have a mean score above the acceptable bench mark of 2.50. which indicates the type of working environment in federal, state, and private universities in Delta State to include irregular promotion, lack of fund for research, lack of modern facilities and equipment, lack of offices, lack of regular pay, poor condition of services, university autonomy violation, poor espirit de corps among academic staff.. 


\section{Research Question 2}

How does the working environment influence the duties of academic staff in Federal, state and private Universities in Delta State?

Table 2: Analysis of mean score and standard deviation of influence of working environment on the duties of academic staff in federal, state and private universities in Delta State academic staff in federal, state and private universities in Delta State

\begin{tabular}{|c|c|c|c|c|c|c|c|c|c|}
\hline \multirow[t]{3}{*}{$\mathrm{S} / \mathrm{N}$} & \multirow[t]{3}{*}{ Items/Statements } & \multicolumn{4}{|c|}{ Responses } & & & & \multirow[t]{3}{*}{ Decision } \\
\hline & & \multicolumn{2}{|c|}{ Federal } & \multicolumn{2}{|l|}{ State } & \multicolumn{3}{|c|}{ Private } & \\
\hline & & Mean & SD & Mean & SD & Mean & SD & Average & \\
\hline 10. & Brain drain & 2.84 & 1.15 & 3.26 & 0.44 & 2.68 & 1.16 & 2.92 & Accepted \\
\hline \multirow{3}{*}{$\begin{array}{l}11 . \\
12 .\end{array}$} & Overwork/stress/burnout & 2.84 & 1.12 & 2.54 & 0.91 & 2.69 & 1.13 & 2.69 & Accepted \\
\hline & Frequent industrial & & & & & & & & \\
\hline & actions. & 2.39 & 1.24 & 3.26 & 0.49 & 2.81 & 1.25 & 2.82 & Accepted \\
\hline 13. & Drop in job satisfaction & 3.40 & 0.94 & 3.35 & 0.56 & 2.63 & 0.95 & 3.12 & Accepted \\
\hline \multirow{3}{*}{$\begin{array}{l}14 . \\
15 .\end{array}$} & Poor job commitment & 2.44 & 0.84 & 3.13 & 0.40 & 2.84 & 0.82 & 2.35 & Rejected \\
\hline & Frequent Distruption of & & & & & & & & \\
\hline & academic calendar & 3.06 & 0.81 & 1.98 & 0.62 & 2.82 & 0.82 & 2.62 & Accepted \\
\hline \multirow[t]{3}{*}{16.} & Diversion of lecturers & & & & & & & & \\
\hline & attention to other & & & & & & & & \\
\hline & activities & 3.22 & 1.03 & 3.37 & 0.53 & 2.50 & 1.04 & 3.03 & Accepted \\
\hline \multirow[t]{2}{*}{17.} & Illness and untimely & & & & & & & & \\
\hline & death & 2.40 & 0.94 & 2.45 & 0.67 & 2.64 & 0.94 & 2.49 & Rejected \\
\hline \multirow{3}{*}{$\begin{array}{c}18 . \\
19 .\end{array}$} & $\begin{array}{l}\text { Reduction in staff } \\
\text { indiscipline }\end{array}$ & 2.84 & 0.65 & 2.40 & 0.86 & 2.72 & 0.68 & 2.65 & Accepted \\
\hline & $\begin{array}{l}\text { Creation of good } \\
\text { management - staff }\end{array}$ & & & & & & & & \\
\hline & $\begin{array}{l}\text { relationship } \\
\text { Continuity in academic }\end{array}$ & 1.84 & 0.36 & 2.53 & 0.77 & 3.15 & 0.79 & 2.50 & Accepted \\
\hline 20. & programmes & 2.39 & 0.81 & 2.29 & 1.01 & 2.91 & 0.72 & 2.53 & Accepted \\
\hline \multirow[t]{2}{*}{$\begin{array}{l}21 . \\
22 .\end{array}$} & $\begin{array}{l}\text { Acceptance of } \\
\text { Responsibilities }\end{array}$ & 2.19 & 0.80 & 2.19 & 1.00 & 2.96 & 0.84 & 2.44 & Rejected \\
\hline & activities & 2.28 & 0.96 & 2.34 & 1.09 & 2.91 & 0.72 & 2.51 & Accepted \\
\hline
\end{tabular}

Table 2 shows ten (10) out of thirteen (13)t items have mean scores which are above the acceptance bench mark of 2.50, that is items 10,11,12, 13, 15, 16, 18, 19, 20 and 21 i.e. (brain drain), overwork and stress, drop in job satisfaction, frequent disruption of academic calendar, diversion of lecturers attention to other activities influence, the duties of academic staff in federal state and private universities, while three (3) out of the thirteen (13) items mean scores of federal and private universities were below the bench mark of 2.50, Showing rejection this include; items 14; poor job commitment, and item 17; illness ultimate death, and items 21 acceptance of responsibilities do not influence the duties of academic staff. The data showed reduction in staff indiscipline, there is creation of good management and staff restitution, continuity in academic programmes, facilitator of academic activities while 
Research Question 3: What are the management strategies employed which influence the productivity of academic staff in Federal, State and Private Universities in Delta State?

Table 3: Analysis of mean and standard deviation of the management strategies employed which influence the production of academic staff and federal, state in private universities in Delta State

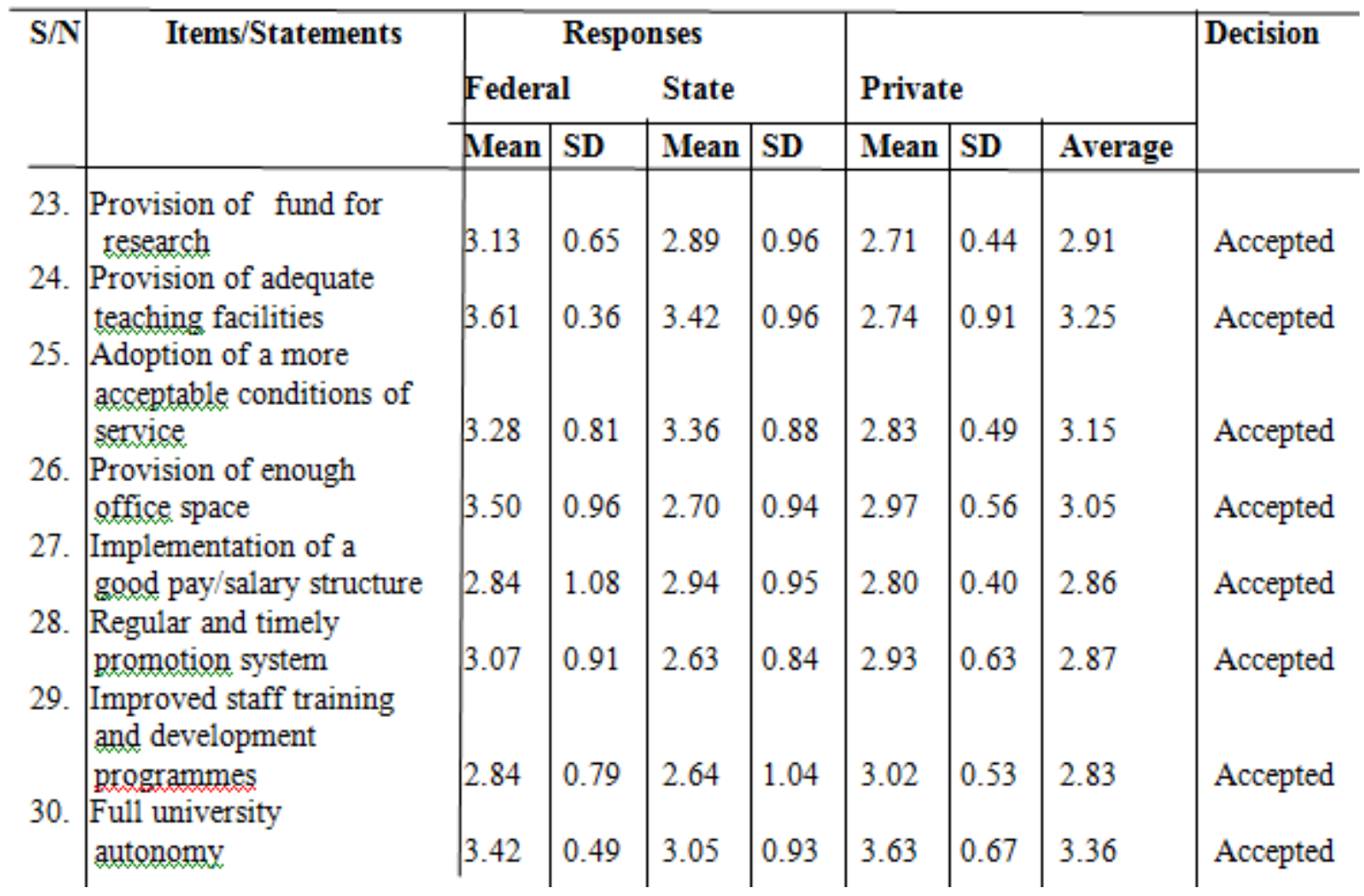

From table 3, it was revealed that the eight (8) items have means score which are above the acceptance bench mark of 2.50 in federal, state and private universities respectively. The items are provision of adequate fund for research, provision of adequate teaching facilities, adoption of a more acceptable conditions of service, provision of enough office space, implementation of a good pay/ salary structure, regular and timely promotion system, improved staff training and development programmes and full university autonomy. Therefore, these management strategies influence the duties of academic staff in federal, state and private universities in Delta State.

\section{Test of Hypothesis}

\section{Hypothesis I}

There is no significant difference in the types of working environment among academic staff in federal, state and private universities of Delta State

Table 4: Anova test of significance difference on the type of working environment among academic staff in Federal, state and private Universities in Delta State.

\begin{tabular}{|c|c|c|c|c|c|c|}
\hline & $\begin{array}{l}\text { Sum of } \\
\text { square }\end{array}$ & $\begin{array}{l}\text { DF } \\
\text { squar }\end{array}$ & Mean & F-Cal & F-Critical & Decision \\
\hline Between & 1.629 & 2 & 0.814 & 11.2434 .32 & & Significan \\
\hline \multicolumn{7}{|l|}{ Groups } \\
\hline $\begin{array}{l}\text { Within } \\
\text { Groups }\end{array}$ & 1.738 & 403 & 0.072 & & & $\begin{array}{l}\text { Reject null } \\
\text { significant }\end{array}$ \\
\hline Total & 3.367 & 405 & & & & \\
\hline
\end{tabular}

Table 4 shows that the F. calculated value is 11.243 while the F. Critical is 4.32 . The null hypothesis is rejected because F calculated is higher than F. critical. 
There is a significant difference in the types of working environment among academic staff in Federal, state and private universities in Delta State Since there is significant difference, the scheffe multiple composition test was applied so as to know where the difference lies.

Table 5: The Scheffe multiple comparison of the types of working environment among academic staff in federal, state and private universities in Delta State.

\begin{tabular}{lll} 
Groups & F & Decision \\
\hline $1 \& 2$ Federal and staff & 2 & Not significant \\
$1 \& 3$ Federal and private & 0.354 & Significant \\
$2 \& 3$ state and private & & \\
universities & 5.635 & Not significant \\
\hline F $=$ Significant at 0.05 & &
\end{tabular}

The various Fs shown in table 5 were evaluated using the same critical F Value (4.32) of the original $F$ test, at 0.05 level of significance, the Scheffe value is 2.883 , it implies that only one of the F in the table shows statically significant, which is for group 1 and 3, while groups 2 and 3 are significantly different from the means group. So also groups 1 and 2. Influence difference between federal and state universities and between state and private universities, there is difference working environment among academic staff in Federal and private universities.

\section{Hypotheses 2}

There is no significant difference in the influence of working environment on the duties of academic staff in federal, state and private universities in Delta State.

Table 6: Anova table showing difference of the influence of working environment on the duties of academic staff in federal, state and private universities in Delta State.

\begin{tabular}{lllllll}
\hline & $\begin{array}{l}\text { Sum of } \\
\text { square }\end{array}$ & DF & $\begin{array}{l}\text { Mean } \\
\text { square }\end{array}$ & F-Cal & F-Critical & Decision \\
\hline Between & 0.790 & 2 & 0395 & 3.413 & 4.42 & * Not \\
Groups & & & & & $\begin{array}{l}\text { Significant } \\
\text { Accept Null } \\
\text { Hypothesis }\end{array}$ \\
$\begin{array}{l}\text { Within } \\
\begin{array}{l}\text { Groups } \\
\text { Total }\end{array}\end{array}$ & 2.431 & 403 & 0116 & & \\
\hline
\end{tabular}

Table 6 showed that the F calculated value of 3.413 is less than the F critical value of 4.42 leading to the acceptance of the null hypothesis that there is no significant difference between the influence of working environment on the duties of academic staff in federal, state and private universities in Delta State.

\section{Hypotheses 3}

There is no significant difference in the management strategies employed to make the working environment more conducive for academic staff in federal, state and private universities in Delta State

Table 7: Anova table showing the difference in the management strategies employed to make the working environment more conducive for academic staff in federal, state and private universities in Delta State

\begin{tabular}{lllllll}
\hline & $\begin{array}{l}\text { Sum of } \\
\text { square }\end{array}$ & DF & $\begin{array}{l}\text { Mean } \\
\text { square }\end{array}$ & F-Cal & F-Critical & Decision \\
\hline $\begin{array}{l}\text { Between } \\
\text { Groups }\end{array}$ & 0.355 & 2 & 0.178 & 2.011 & 4.42 & $\begin{array}{l}\text { Not } \\
\text { * Accept } \\
\text { Significant } \\
\text { Null }\end{array}$ \\
& & & & & Hypothesis \\
$\begin{array}{l}\text { Within } \\
\begin{array}{l}\text { Groups } \\
\text { Total }\end{array}\end{array}$ & 1.855 & 403 & 0.088 & & \\
\hline
\end{tabular}


Table 7 showed that the F-calculated is lesser than the F-critical value leading to the acceptance of the null hypothesis that there is no significant difference between the management strategies employed to make the working environment more conducive for acceptance staff in federal, state and private universities in Delta State.

\section{Discussion of Findings}

Findings from this study revealed a high level of poor working environments in the federal, state and private universities in Delta State. These include: irregular promotion, lack of funds for research, lack of modem teaching facilities, lack of office space, poor conditions of services, inadequate staff development programme and poor spirit de corps. The result clearly showed that federal universities when compared to state universities had no significant difference but when compared with the private universities there is significant difference. However, on comparing state against private universities, the working environment showed no significant difference. Findings from this study does not vary with the submissions of Egbule (2003) who posited that lecturers in federal universities are satisfied with the eleven of the twelve job satisfaction factors task include: pay/salary, job security, achievement/recognition, opportunities for promotion, style, attitude, work environment (physical), staff development programmes, academic freedom, responsibility at work, supervision, university autonomy and interpersonal relations. Further investigations according to Egbule, (2003) show that the lecturers in private universities receive lower pay/salaries than their counterparts in federal and state universities.

This finding is in line with Ugwo (2017) who noted that working environment impact greatly on the level of motivation and performance which it negative, has proved to be associated with reduced job satisfaction, absence teeism, somatic complaints, turnout and depression phenomenon's. On adequate funding, finding from this study are in agreement with those of Oyeneye (2006) and Adegbite (2007) who noted that the major challenge facing the university system in Nigeria is inadequate funding. McCowan (2001), the findings from research question two and hypothesis two revealed that Unfavorable work conditions have contributed to mass exodus (brain drain), overwork and stress:, drop in job satisfaction frequent disruption of academic calendars, diversion of lecturers' activities in federal state and private universities except for poor job commitment, frequent industrial actions which has not affected federal and private universities. Sadly, the results of the study proved that the influence of unconducive working environment on the duties of academic staff in Federal, state and private is the same.

In the same vein, Findings on the management strategies that can be employed in managing work environment among academic staff of federal, state and private did not show any statistical significant difference and were identified to include Provision of adequate teaching facilities and funding for research, adoption of a more acceptable conditions of service, implementation of a good pay/salary structure, main the ongoing regular/timely promotion system, improvement of staff development and training and full university autonomy. These submissions are in line with those of Ochuba, (2001) who noted that if quality is to be enhanced in our nation's universities the infrastructure base of the system needs to be improved upon and called upon the government and university proprietors to make available enough funds for the rehabilitation of existing facilities.

This also supports the research of Ajayi (2011) which recommended that the management of universities should make work environment more conducive by giving more attention to the provision of physical facilities, authority staff relationship, staff participation in decision making and staff development.

\section{Summary}

This study was designed to analyze the working environment among academic staff in Delta State, federal, state and private universities. The hypotheses were formulated, a structured research questionnaire titled "working environment among academic staff in federal, state and private universities in Delta State" was used to collect data from the academic staff of three universities in Delta State as at the 2014/2015 academic session. The ANOVA and Scheffe test was used for the data analysis of all the hypotheses at 0.05 level of significance. Through stratified random sampling and purposive sampling $40 \%$ academic staff members were selected from the universities. The researcher using the adapted Likerts' to construct the instrument used for the academic members of staff. The instrument was validated using experts' opinion. Data was based on descriptive statistics and expressed as mean and standard deviations while hypotheses were tested using ANOVA for group items mean comparisons while a Scheffe test was employed to compare differences across universities.

\section{Findings of the Study}

Based on the data analyzed, the following findings enumerated

1. Profile of type of working environment of universities iii Delta state constitutes irregular promotion, lack of fluids for research, lack of modern teaching facilities, lack of office spaces and standard pay, poor conditions of services 
inadequate staff development programme and poor spirit de corps. This poor condition cuts across the federal, state and private universities but showed significant difference on the extent to which these occurs.

2. The influence of working environment on the duties on academic staff have led to mass exodus (brain drain), overwork and stress, drop in job satisfaction equent disruption of academic calendars, diversion of lecturers' activities the deral, state and private universities and showed no significant difference

3. The strategies that can be employed in managing work environment arid the productivity of academic staff of federal, state and private Universities include Provision of adequate teaching facilities and funding for research, adoption of a more acceptable conditions of service, implementation of a good pay/salary structure, maintain the ongoing regular/timely promotion system, improvement of staff development and training and full university autonomy all these strategies showed no significant difference across federal, state and private universities.

\section{References}

Adegbite, J.G.O (2007). The Education Reform Agenda: Challenges for Tertiary Education Administration in Nigeria; being a Paper Presented at the Sixth Annual Seminar of the Conferences of Registrars Of colleges of Education TN Nigeria (South West Zone ) at the College of Education, Ikere-Ekiti, Ekiti State

Ajayi I. A, Ekundayo H.T. (2006). Funding Initiatives In University Education in Nigeria. Being a Paper Presented at the National Conferences of Nigerian Association for Educational Administration and Planning NAEAP). Enugu State University of Science and Technology, Enugu State.

Anho J.E. (2017). Relationship between Fiscal and Physical Resources as Administrative Variable and Delta State Secondary School ifecipals Competence in a Depressed Economy. ABSU Journal of Educational Studies vol. 4(3) pp 46-56. Faculty of Education, Abia State University, Uturu.

De Chiara, J. \& Crosbie M .J (2001). Time Saver Standards for Building Types. Singapore. McGraw Hill

Duncan RB. (1972). "Characteristics of Perceived Environment Uncertainty” Administrative Quarterly 17,320.

Egbule, P.E. (2003). "Publication in Foreign Journals and Promotion of Academics in Nigeria". Learner Publishing, Vol. 16, No 4 pp. 259-263 Federal Republic of Nigeria (2011). National Policy on Education, Abuja NERDC

Ibukun W.O (1997). Educational Management: Theory and Practice. Ado Ekiti: Green Line Publishers.

Jones A. \& James L.(2004). "Psychological Climates: Dimensions and Relationship of Individual and Aggregated Work Environment Perception" Organizational Behavioural and Human Performance, Vol. 23, pp. 20 1-250

McCowan, B. (2001). Self Reported Stress and its Effects on Nurses. Nursing Standard Vol. 42, pp 33-38.

Ochuba, V.O. (2001). Strategies for improving the Quality of Education in Nigerian Universities. In N.A Nwagwu, F.T Ehiametalor,'M.A. Ogunu and Nwadiani (eds). Currents Issues in Educational Management in Nigeria. A publication of the Nigerian Association for Educational Administration and Planning.

Okeke B.S. (2004). Teaching in Nigeria: The Bureaucracy and Professionalism. Port Harcourt. Mercury International Publishers, Nigeria Vol. 2 pp 89-91

Oyeneye, O.Y. (2006). Current Issues in the Administration of University Education in Nigeria. Lecture Delivered at the Convocation Ceremony of University of Ado-Ekiti, Ado-Ekiti, On March 29

Ugwo, B.C. (2017). Work environment and non-academic staff job performance in colleges of education in Delta State. 